\title{
Classroom Management for Early Childhood Group Setting
}

\author{
Dewi Komalasari, Novy Cici Jayanti \\ Department of Early Childhood Education \\ Universitas Negeri Surabaya \\ Surabaya, Indonesia \\ dewikomalasari@unesa.ac.id
}

\author{
Dewi Kartikasari \\ Indonesian Institute of Sciences (LIPI) \\ Jakarta, Indonesia
}

\begin{abstract}
The creativity of classroom management in early childhood is very important in fostering children's learning interest. Through this study aims to describe the creativity of classroom management by setting a group classroom with a safety angle by the teacher and the way the teacher fosters children's learning interest. Data collection techniques used were observation, interviews, and documentation. Data analysis techniques using the model of Miles and Huberman which has three steps of data analysis namely: data reduction, data presentation, and conclusions. The results showed that the creativity of teachers in classroom management to foster children's interests has been well implemented in accordance with STPPA (Unit for Achieving Child Development) and K13 (Kurikulum 2013 - the 2013 Curriculum). Supported by varied media and activities, so as to be able to attract the attention of children in participating in activities and the teacher is able to focus the attention of children and create a friendly atmosphere. A careful and mature strategy, and through new ideas carried out by the teacher in determining the creative actions of classroom management, have an impact on children's interest in learning. Seen from the child is very interested in doing activities, so as to be able to motivate children's learning in the classroom.
\end{abstract}

Keywords-creativity; classroom management; group settings; children's learning interest

\section{INTRODUCTION}

Early childhood is an individual who is undergoing a process of growth and development that is very fast, even said to be a developmental leap. So that the form of educational services for children aged 0-6 years is provided before entering primary education. The goal is to achieve child development maturity, which is to ensure that all developmental tasks can grow, develop, and have no obstructive aspects [1].

Based on that, service delivery must be supported by teacher performance competencies regulated in the Teacher and Lecturer Law No. 14 of 2005 which constitutes formal legality that guarantees legal protection for teachers to be able to work safely, creatively, professionally, and pleasantly. As well as demanding teachers to have a set of integrally holistic competencies namely pedagogical competencies, personality competencies, professional competencies, and social competencies.

One part of pedagogical competence is proper classroom management by the teacher. In Government Regulation No. $19 / 2005$ it is explained that the ability to manage learners 'learning which includes students' understanding, design and implementation of learning, evaluation of learning outcomes, and student development to actualize the various potentials they have. Thus the classroom management activities will help the child's optimal development process in accordance with the stated goals [2].

Teachers play a role more than just teaching, but also as educators. Teachers must be able to use various approaches in the process of learning activities and guide their students [3]. In managing teacher classes Adopting an approach of culturally responsive classroom management, including becoming aware of one's bias as a teacher, monitoring classroom management for disproportionality, and getting to know students' families and communities, can lead to a new view of classroom management [4].

Class management can also be interpreted as an effort to create an atmosphere or class conditions that allow students or students to learn effectively.

The teacher has tried to do his tasks in managing the class creatively so that children can learn and play with fun, which is marked by the awareness of the teacher to create new ideas so that the material presented is easily understood by children. Besides classroom management conducted by the teacher also should be able to foster children's interest in learning.

Promoting creative learning experiences poses a pedagogical challenge as early childhood teachers struggle to balance between the development of content knowledge, child-centered learning experiences, and active and play-based learning [5]. Interest is "driving" a conscious effort to influence a person's behavior so that he was moved to act do se a so as to achieve a particular result or goal [6].

Based on the results of observations beginning in February 2018, class management by teachers aims to improve children's learning interest is good. The teacher uses varied learning media in learning activities and attractive classroom 
designs so that children are enthusiastic to participate in learning. In the learning process, of course there are many difficulties faced, difficulties occur, which are not suitable media for children of this age.

Based on the description above, the focus of this research problem are class management creative by teachers and how teachers fostering children's learning interest group $\mathrm{A}$ in kindergarten X, Mojokerto.

\section{METHOD}

This research uses qualitative research with a case study approach. Case study aims to intensively study the social particular unit, which includes individuals, groups, families, and communities. Furthermore, Azwar explained the case study was an in-depth investigation of a social unit in such a way that it produced a well-organized and complete picture of the social unit [7]. This study was conducted to explore the data and information that associated with creativity class management by teachers in growing interest in studying child group TK A which will be described and explained in a wellorganized and complete accordance with the facts and characteristics of the research results.

The subjects of this research are Kindergarten $\mathrm{X}$, Mojokerto and what will be discussed is the creativity of classroom management by the teacher and children's interest related to the creativity of classroom management. This research was conducted in the second semester of 2018-2019. Observation data collection techniques used to obtain data based on direct observation in accordance with the application of classroom management creativity by teacher and fostering children's learning interest. Interview data collection techniques are used to explore data and information from teachers about the knowledge and application of classroom management creativity in fostering children's interest in learning. Documentation data collection techniques are used to support and explain the data and information that has been obtained in the form of writing daily activity plans, weekly activities, annual activities, portfolio of children's learning activities and art works (Educational Educative Games (APE) , learning media, and results children's work).

The analysis techniques used in this study are data reduction, data display and conclusion drawing or verification (drawing conclusions or verification) [8].

\section{RESULTS AND DISCUSSION}

From the observation, interviews and documentation, the result of research is divided into five topics of spatial learning, plan and setting class, infrastructure, execution steps and the process of learning. From the results of research on spatial planning study can be seen that the learning model group A in kindergarten X, Mojokerto has a division 3 groups of children in the class, with the name of groups: red, yellow group, and blue. Each of group have two tables and six chairs.

Classroom arrangement in the group learning model looks pretty neat. The situation in the classroom is quite colorful with the presence of some wall hangings and the lighting is good with the ventilation of the window. Inside the classroom there is a blackboard, desk and children's chair, teacher's desk and chair, carpet, stationery and book storage lockers, media storage rack, APE storage rack, safety corner, TV and sound, carpet, and tool storage cabinets and play materials child.

Seating arrangements for children are in accordance with their respective seats that have been arranged by the teacher. During the initial activity (opening) the children sit in a circle on the carpet to do prayer, greetings, apresception, and explain the 3 activities that will be carried out. When the core activity (children's learning activities) children sit in each seat that has been provided in each group, then the teacher explains again 3 activities that will be carried out by the child in the group. Children who have finished the activity immediately report to the teacher, if in another group there is an empty seat the child can occupy it to do other tasks, if there is no empty seat the child must wait for him to play in the corner of safety. During the final activity (closing) the children sat back in a circle on the carpet to do the final activity, recalling, delivering tomorrow's activities, preparing to go home, and praying. when attempting to provide quality learning environments. Moreover, motivation and learning are interrelated not the least through the social aspects, especially in play [9].

The results of the study of the plan and setting of group A in the classroom arrangement, will be described as follows: storage cabinets for children's play equipment and materials, media shelves, shelves for APE, and children's lockers are placed in the corner of the room. Next the blackboard placed in front of, desks and carpet child seat placed facing the blackboard. There are two fans placed beside the blackboard.

The position of the child's seat and floor plan or classroom settings are changed every month by the teacher. So that children can socialize with other friends and not get bored while doing activities in the classroom. The following is the layout and class setting for Group $\mathrm{A}$ in Kindergarten $\mathrm{X}$ in March and April.

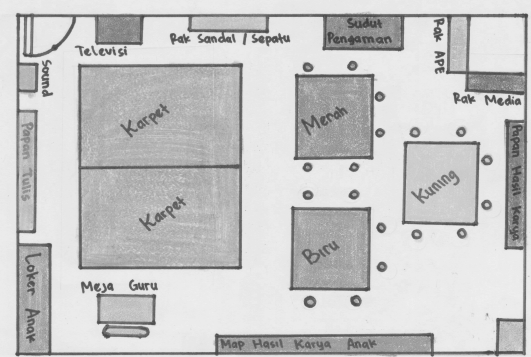

Fig. 1. Plan and Classroom Settings in March

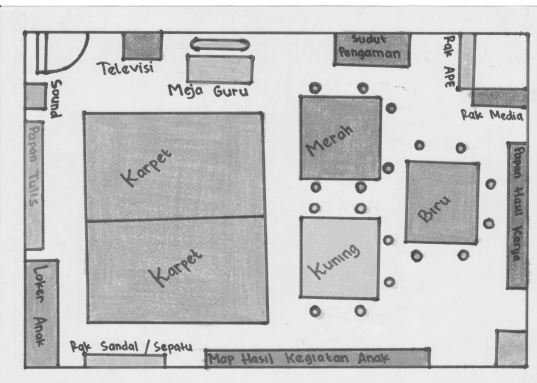

Fig. 2. Plan and Classroom Settings in April 
Facilities and infrastructure used in Group A class include; APE and media (stationery, whiteboards, wall decoration according to the theme created by teachers, flannel board, storybook, Worksheet Kids (LKA) ), Equipments in the classroom are tables, chairs, carpet, shelves and storage cabinets media, lockers and binder storage of children's work, decoration of learning themes on the walls of children's work and electric fan.

The facilities and infrastructure are used in daily learning activities, namely the use of APE and media for learning activities that are in the room. APE that is used is not only APE made by the factory but also APE made by the teacher. One of them when teaching the art of music. Children play the sound of the tone through glass bottles filled with beaten water.

The results of the study of the implementation and learning process in class Group A are divided into several stages: a. Main environmental management, b. Welcoming children, c. Morning material, d. Initial activity (opening), e. Children's learning activities, f. Food and play activities (rest), g. Final activity (closing)

The creativity of classroom management by the teacher is a new idea or idea to create a conducive atmosphere and learning conditions. Creativity in classroom management by teachers in TK X. In learning activities include planning and implementation. Planning carried out in $\mathrm{T} X$ starts from planning learner activities, the use of tools and media, as well as the pursuit strategy that will be carried out. Classroom management is an effort done systematically by the teacher which starts from planning learning activities, preparing supporting facilities, managing children's activity time, arranging classrooms, and building a conducive classroom climate for effective children's learning. So the learning planning process in classroom management is in accordance with that opinion.

Whereas the implementation (the way the teacher teaches) carried out in Kindergarten X starts from the familiarity of the teacher and child in the activity of welcoming the arrival of children to school. Welcoming activities are regulated in the school's SOP (Operational Procedure Unit), which aims to condition children to be ready to learn. The atmosphere of the school is made beautiful and many colorful decorations according to the big theme set by the school which is the theme of Animals. Classes are also decorated based on sub themes that have been determined by schools based on class agreement. These are sea dwelling animals, forest dwelling animals, domesticated dwelling animals, the results of these observations are an effort to create an atmosphere and classroom conditions that allow children to learn effectively. So that classroom management by the teacher fosters children's learning interest.

The creativity of classroom management by teachers in Kindergarten $\mathrm{X}$ in learning includes learning planning and implementation (the way the teacher teaches). But according to Purwanto [10], the stages in learning basically include planning, implementing, and evaluating. However, classroom management by teachers in Kindergarten $X$ has not been evaluated thoroughly and in detail. The teacher only evaluates the activities. This is because teachers do not understand the evaluation activities in the 2013 PAUD curriculum. Teachers utilized multiple modes of encountering a "day in the life" video via video cues, micro-analyses, and recursive observations [11]. Evidence of program quality is determined not just by the number of students who successfully complete the program; rather, evidence of program quality focuses on expected student performance and on assessments of student work [12].

The focus of teacher creativity in classroom management in Kindergarten $X$ includes 2 stages: 1). The teacher's way of planning learning begins with formulating learning objectives or instructional goals well, choosing appropriate learning methods for children, creating appropriate media or props and attracting interest. 2). The way the teacher is in carrying out the learning process / the way the teacher teaches is seen twoway communication. The teacher uses clear intonation and use of language that is easily understood by children. The speech position is set so that it is level with the child's eyes when communicating and giving material. The attitude and behavior of teachers who are polite to take an example to their students. The professional development model (PDM) was constructed on a socio-cultural theoretical framework whereby Vygotsky's zone of proximal development was applied in the context of early years professional development [13].

The creativity process of classroom management undertaken by the teacher arouses the interest of the child. Children become anthusiastic in their assignments, increase their enthusiasm for children to learn, and patterns of good interaction between teacher and child.

Based on the explanation above it was concluded that the creativity of classroom management by teachers applied in TK $\mathrm{X}$ was more to the way the teacher planned the learning and the way the teacher carried out the learning process. Child-led, interest-inspired learning mitigated learning difficulties. Less flexible regulatory policies and processes impacted negatively on student learning by restricting the opportunity for child-led, interest-inspired learning. Some learners require a different approach to be successful [14].

Children's interest in Kindergarten A is an encouragement for children to be interested in participating in learning activities and acting to complete their tasks so as to achieve learning outcomes or goals.

Children's interests are described as follows: 1). The desire and desire to learn is marked by children willing to follow the learning activities to completion. 2). The child is able to complete the tasks given to him.

Creative classroom management by teachers in Group A TK $\mathrm{X}$ is carried out with a careful and mature strategy, through searching for information on new ideas about learning activities on Youtube and Facebook. After that, the teachers were drawn together to take a collective agreement and applied it in the form of SOP and learning activities in Kindergarten $\mathrm{X}$ The use of SOP in class management creativity by teachers aimed in an orderly, well-implemented and responsible manner. The SOP conducted by the teacher is in line with Arikunto's opinion that the purpose of orderly 
classroom management is not a rigid and tense atmosphere in conducting activities, but an orderly means the existence of order based on the existence of systematic class planning and organization. Successful implementation of response to intervention may require early childhood practitioners to develop new skills in assessment, intervention, and data-based decision making [15].

This situation results in orderly behavior that is supported by a sense of joy, pleasure, motivated by children to interact with the learning environment.

Creative classroom management by the teacher in fostering children's learning interest makes changes to the child's development, so it does not rule out the possibility that with creativity classroom management by the teacher can motivate children's learning, especially interest when doing learning activities in Group A.

Creative classroom management by teachers on the interests of children Group A in Kindergarten X shows that: 1 . The creativity of learning planning by teachers in motivating children's learning has largely been well structured in accordance with STPPA (Unit for Achieving Child Development) and K13 (Kurikukulum 2013). Supported by varied media and activities, so as to be able to attract the attention of children in participating in activities, 2. Creativity in the way teachers teach in motivating children's learning is mostly good and attracting children's interest to learn is seen from; teacher and child familiarity, the child's interest in participating in activities, and the teacher is able to focus the attention of the child and conversely the teacher can focus on the child. For this reason, this study attempted to visualize the structure of knowledge in an educational game. In other words, a knowledge map was visualized and gamified so that students could make decisions to construct their own knowledge map in games [16].

A case study design was used in the current study. Findings indicated that the student teachers described the 'creative school' as a space for active engagement, supporting inquiries of children through play-based activities, design of nature- and community-based schools, child participation and freedom of speech, and open-ended experiences [17].

\section{CONCLUSION}

Based on the results of the study, creative classroom management in early childhood in fostering children's interest in learning in Group A TK X shows that: 1) Creative classroom management in fostering children's interest in learning has largely been well structured in accordance with STPPA (Unit Level of Achievement in Child Development) and K13 (Kurikulum 2013). Supported by varied media and activities, so as to be able to attract the attention of children in participating in activities, 2 ). The way teachers foster children's learning interest is seen from; teacher and child familiarity, the child's interest in participating in activities, and the teacher is able to focus the attention of the child and conversely the teacher can focus on the childAuthors and Affiliations.
A careful and mature strategy, as well as through new ideas done by the teacher in determining measures of classroom management that creative impact on the activeness of children in learning. Seen from the children are very interested in doing activities, so that with creative classroom management by the teacher can motivate children's interest in learning and children want to complete their assignments.

From the conclusion above, it may put forward suggestions as follows: 1) advice for teachers are they should pay more attention to the principles of learning, so teachers do not just focus on the planning and implementation (way teachers teach), but teachers should also be able to evaluate thoroughly and in detail . The teacher must be able to understand each stage of his development, stimulation and evaluation. So that the child's development can grow optimally. ,2) the researcher can develop this research to measure the relationship management of the creative class to measure the relationship between creative classroom management and children's learning outcomes which in this study have not been resolved.

\section{REFERENCES}

[1] Masnipal, "Menjadi Guru PAUD Profesional," in Menjadi Guru PAUD Profesional, Kesatu, 20., Bandung: PT Remaja Rosdakarya, 2018, p. 400.

[2] Y. Rachmawati and E. Kurniati, "Strategi Pengembangan Kreativitas Pada Anak TK," in Strategi Pengembangan Kreativitas Pada Anak TK, Pertama., Jakarta: PT. Kencana Prenada, 2000, p. 200.

[3] Rusdinal and Elizar, "Pengelolaan Kelas di Taman Kanak-kanak," in Pengelolaan Kelas di Taman Kanak-kanak, Pertama., Departemen Pendidikan Nasional, 2005, p. 211.

[4] L. H. Koops, "Classroom Management for Early Childhood Music Settings," Gen. Music Today, p. 104837131875699, 2018.

[5] E. Angela, "Creativity in the early childhood classroom: Perspectives of preservice teachers," J. Early Child. Teach. Educ., vol. 32, no. 3, pp. 240-255, 2011.

[6] N. Purwanto, Psikologi Pendidikan, Pertama. Bandung: PT Remaja Rosdakarya Offset, 2014.

[7] S. Azwar, "Metodelogi Penelitian," Kelima Bel., Yogyakarta: PT Pustaka Pelajar, 2015, p. 146.

[8] Sugiyono, "Metode Penelitian Kuantitatif, Kualitatif, dan R\&D," in Metode Penelitian Kuantitatif, Kualitatif, dan $R \& D$, Kedelapan., Bandung: Alfabeta, CV Bandung, 2011, p. 380.

[9] O. F. Lillemyr, F. Søbstad, K. Marder, and T. Flowerday, "A Multicultural Perspective on Play and Learning in Primary School," Int. J. Early Child., vol. 43, no. 1, pp. 43-65, 2011.

[10] G. Talajan, "Menumbuhkan Kreativitas dan Prestasi Guru," in Menumbuhkan Kreativitas dan Prestasi Guru, Kesatu., LaksBang PRESSindo, 2012, p. 169.

[11] M. J. Moran, C. Bové, R. Brookshire, P. Braga, and S. Mantovani, "Learning from each other: The design and implementation of a crosscultural research and professional development model in Italian and U.S. toddler classrooms," Teach. Teach. Educ., 2017.

[12] S. N. Ritblatt, S. Garrity, S. Longstreth, A. Hokoda, and N. Potter, "Early Care and Education Matters: A Conceptual Model for Early Childhood Teacher Preparation Integrating the Key Constructs of Knowledge, Reflection, and Practice," J. Early Child. Teach. Educ., 2013.

[13] D. J. McMillan, G. Walsh, C. Gray, K. Hanna, S. Carville, and O. McCracken, "Changing mindsets: The benefits of implementing a professional development model in early childhood settings in Ireland," Prof. Dev. Educ., 2012.

[14] G. Liberto, "Child-led and interest-inspired learning, home education, learning differences and the impact of regulation," Cogent Educ., 2016.

[15] K. Albritton, S. D. Truscott, and N. P. Terry, "Exceptional Professional 
Learning for RtI Implementation in Early Childhood Settings," Contemp. Sch. Psychol., 2018.

[16] C. Y. C. Yeh, H. N. H. Cheng, Z.-H. Chen, C. C. Y. Liao, and T.-W. Chan, "Enhancing achievement and interest in mathematics learning through Math-Island,” Res. Pract. Technol. Enhanc. Learn., 2019.

[17] S. Ucus and I. H. Acar, "Exploring the perceptions of student teachers about 'creative school' in early childhood education," Early Child Dev. Care, 2019. 